\title{
PRINSIP ISLAM DALAM MELINDUNGI HAK MINORITAS
}

\author{
Linda Novianti \\ Pascasarjana UIN Sunan Gunung Djati Bandung \\ E-mail : lindanovianti999@gmail.com
}

\begin{abstract}
This study aims to encourage the creation of a sense of security and peace for religious minorities in carrying out their obligations as religious communities. Muslims are faced with a situation where the issue of minorities is an important issue to raise, because the issue of minority has in principle been taught and practiced directly by the Prophet Muhammad SAW while in Medina in the form of the constitution of Medina as guided by the Al-Quran and Al-Hadith. This research is included in descriptive research. The results of this study concluded that Islam as a religion that teaches its people that plurality and plurality are sunatullah which need not be questioned as long as they do not conflict with the values of faith and human rights. Then Islam observes that the protection of minority rights is the prevention of economic, social, cultural, political and legal discrimination with the aim of equalizing positions without imposing boundaries based on differences from one another.
\end{abstract}

Keywords: Minority Rights; Protection; Islamic Principles

\begin{abstract}
Abstrak
Penelitian ini bertujuan untuk mendorong terciptanya rasa aman dan damai bagi agama minoritas dalam melaksanakan kewajibannya sebagai umat beragama. Umat Islam dihadapkan pada situasi di mana persoalan minoritas menjadi suatu hal yang penting diangkat, pasalnya persoalan minoritas pada prinsipnya telah diajarkan dan dipraktikkan langsung oleh Nabi Muhammad SAW ketika di Madinah dalam bentuk the constitution of medina sebagaimana tuntunan Al-Quran dan Al-Hadist. Penelitian ini termasuk ke dalam penelitian deskriptif (descriptive research). Hasil penelitian ini menyimpulkan, Islam sebagai agama yang mengajarkan kepada umatnya bahwa kemajemukan dan pluralitas merupakan sunatullah yang tidak perlu dipersoalkan selama hal tersebut tidak bertentangan dengan nilai-nilai keimanan dan HAM. Kemudian Islam meninjau bahwa perlindungan hak minoritas merupakan pencegahan diskriminasi secara ekonomi, sosial, budaya, politik dan hukum dengan tujuan menyamakan kedudukan tanpa memberikan batasan berdasarkan perbedaan satu sama lain.
\end{abstract}

Kata kunci: Hak Minoritas; Perlindungan; Prinsip Islam 


\section{Pendahuluan}

Hak minoritas menjadi salah satu persoalan fiqh yang sampai saat ini masih ramai diperdebatkan. Pasalnya berbicara minoritas terkadang menjadi sesuatu yang sulit dipecahkan oleh sebagian umat. Bahkan dunia barat menganggap Islam tidak mengenal konsep hak minoritas, begitupun kejadian-kejadian yang terjadi diakibatkan oleh beberapa oknum yang mengatasnamakan Islam melakukan praktik intoleran terhadap kelompok minoritas, sehingga memperparah pemberitaan nasional dan internasional terhadap Islam, padahal itu semua tidak dibenarkan. Alhasil dunia barat menganggap bahwa hak-hak minoritas hanya ada di negaranegara barat sekuler bukan Islam ${ }^{1}$.

Pada dasarnya, konsep Hak Asasi Manusia telah mengalami perkembangan yang signifikan, sehingga dijadikan sebagai alat dalam menjerat atau mungkin bahkan sebagai media untuk menjatuhkan seseorang. Hal tersebut dapat terlihat dari makna HAM itu sendiri yang mengalami reduksi dan derivasi makna. Oleh karenanya, HAM dapat disimbolkan seperti halnya dua sisi yakni sisi humanisme dan alat yang menakutkan bagi penguasa. Statement ini kerap kali muncul, sebab secara hakikat setiap manusia mempunyai hak dasar (al-huquq al-thabi'yah), sehingga manusia memiliki kebebasan alamiah (hurriyah) yang mampu memunculkan kebebasan dan kehumanisan individu².

Hubungan antar umat beragama seharusnya dapat membawa pengaruh positif terhadap masing-masing penganutnya. Agama menjadi pijakan dalam memahami nilai-nilai dasar keagamaan. Sehingga sangatlah penting untuk bersikap kritis dan bertanggung jawab dalam tindakan yang akan dilakukan dalam interaksi antar umat beragama. ${ }^{3}$

Setiap agama menisbatkan dirinya sebagai agama yang sempurna dan paripurna. Begitupun dengan Islam, kepercayaannya merupakan agama yang sempurna dan paripurna serta berada pada puncak kesempurnaan dengan segala konsep tertentu. Konsep yang dimaksudkan menyangkut aqidah, syariah serta muamalah. Konsep demikian dapat terlihat jelas jika Islam memiliki pondasi ketentuan syariat dan

1 Akhmad Solikhin, "Islam, Negara, dan Perlindungan Hak-Hak Islam Minoritas", dalam Journal of Governance, Volume 1, Nomor 2, Desember 2016, hlm. 43.

2 Naimatul Atqiya, HAM dalam Perspektif Islam, dalam Jurnal Islamuna Nomor 1 Volume 2 Desember 2014, hlm. 171-172.

3 Dadang Kahmad, Multikulturalisme Islam dan Media, (Bandung : Pustaka Djati), 2013, hlm. 78. 
fiqh. Abu A'la al-Madudi berpendapat bahwa terkandung dua konsep hak, yakni huquq al-insan dan huquq Allah ${ }^{4}$.

Kedua konsep hak tersebut yang kemudian membedakan antara gambaran konsep Hak Asasi Manusia perspektif Islam dan Barat. Lebih jauh dari itu, Islam memiliki konsep akan tingkatan bentuknya, yakni darury (hak dasar yang jika dilanggar akan membuat kehilangan eksistensi harkat kemanusiaan), meliputi adh-dharuriyat al-Khams, hajy (hak yang jika tidak terpenuhi akan menghilangkan hak-hak elementer), dan tahsiny (hak yang sifatnya tersier) ${ }^{5}$.

Penelitian sebelumnya menunjukkan bahwa perbincangan mengenai hak-hak minoritas dalam menjalankan kewajibannya sebagai umat beragama masih beragam. Beberapa penelitian menggambarkan bahwa praktik intoleransi dan kekerasan oleh sekelompok masyarakat tertentu terhadap beberapa kelompok minoritas juga banyak menghiasi pemberitaan di media nasional dan internasional ${ }^{6}$. Selain itu juga terlihat bahwa kemajemukan dalam hal agama dan keyakinan yang ada dalam masyarakat Indonesia, tidak semudah membalikan telapak tangan untuk melakukan harmonisasi terhadap keduanya, sehingga ada kalanya ketegangan muncul dari hal kecil terkait agama. Pancasila hadir di tengah-tengah masyarakat Indonesia yang majemuk dalam rangka mempersatukan semua masyarakat dengan latar belakang yang berbeda-beda tapi tetap satu jua7.

Penelitian ini bertujuan untuk mendorong terciptanya rasa aman dan damai bagi agama minoritas dalam menjalankan kegiatannya, dengan tetap menjalankan prinsip-prinsip kemajemukan, baik minoritas yang ada di Indonesia maupun minoritas Islam yang berada di negara lain. Sebagai contoh Kelompok minoritas Muslim Rohingya di Myanmar, Muslim Uighur di Xingjiang Tiongkok, Muslim India yang keberadaanya ditindas akibat disahkannya Undang-Undang Kewarganegaraan oleh Pemerintah setempat. Dari deretan kejadian tersebut Islam menerapkan prinsip-prinsip berkeadilan terhadap hak-hak minoritas.

4 Abu A'la Al-Maududi, “Hak Asasi Manusia dalam Islam”, (Jakarta : YAPI), 1998, hlm. 13.

${ }^{5}$ Naimatul Atqiya, Ibid.,, hlm. 174.

${ }^{6}$ Akhmad Solikhin, "Islam, Negara, dan Perlindungan Hak-Hak Islam Minoritas", Op.Cit., hlm. 43.

7 Endra Wijaya, "Problem Melindungi Hak Beragama dan Berkeyakinan Bagi Kelompok Minoritas", Jurnal Yudisial Vol. 10 No. 2 Agustus 2017, hlm. 135. 


\section{Metodologi}

Penelitian ini dimaksudkan untuk mendeskripsikan perlindungan hak-hak minoritas dalam masyarakat Indonesia terutama yang berkaitan dengan prinsip-prinsip keimanan dan HAM. Berdasarkan maksudnya, penelitian ini termasuk ke dalam penelitian deskriptif (descriptive research). Dengan metode ini, penguatan terhadap hak minoritas digambarkan sebagai sebuah situasi atau kejadian berdasarkan proses akumulasi dari jenis data terkait. ${ }^{8}$ Data yang berhubungan dengan hak minoritas dihimpun secara sistematis dengan senantiasa mempertimbangkan aktualitas dan akurasinya. ${ }^{9}$ Implementasi dari pelaksanaan perlindungan Islam terhadap hak minoritas sebagai perwujudan dari prinsip Hak Asasi Manusia diharapkan dapat disajikan dalam suatu gambaran yang relatif baru. ${ }^{10}$ Jadi, penelitian ini berusaha menghimpun dan mengakumulasikan data secara sistematis, faktual, dan akurat dalam rangka menemukan dan menyajikan informasi yang baru dan mendalam mengenai Prinsip Islam dalam melindungi Hak Minoritas.

\section{Konsep Kebebasan Beragama dalam Islam}

Hakikatnya manusia terlahir dalam keadaan merdeka (freedom) dan suci, maksudnya hak ini merupakan sesuatu yang mutlak dimiliki oleh setiap manusia dalam bingkai kehidupannya di dunia. Begitupun dengan kebebasan dalam menjalankan keyakinannya kepada Tuhan Yang Maha Esa tidak dapat diinterpensi oleh siapapun. Kebebasan tersebut menjadi sebuah keharusan bahwa hak-hak tersebut dilindungi baik oleh kelompok mayoritas maupun Hak Asasi Manusia dalam hal berkumpul, memberikan penerangan, menerima, dan mengajarkan agama. Selain itu juga diimbangi dengan penerapan kebebasan beragama dalam aspek sosial, ekonomi, hukum, dan politik pada lingkup nasional maupun internasional ${ }^{11}$.

Setiap individu berhak memilih dan meyakini kepercayaannya terhadap salah satu agama dengan diimbangi pengamalan sepenuh hati terhadap agama yang diyakininya. Dalam hal ini, Islam tidak memaksakan kehendak dan tidak diperbolehkan memaksakan keyakinan kepada orang

\footnotetext{
${ }^{8}$ M. Nazir, Metode Penelitian (Jakarta: Ghalia Indonesia, 1983), hlm. 51.

${ }^{9}$ S. Suryadibrata, Metode Penelitian (Jakarta: Rajawali Press, 1991), hlm. 18.

10 K. W. Eckhardt, Social Research Methods: Perspective, Theory, and Analysis (New York: Random House Inc., 1977), hlm.

11 Mukti Ali, Dialog Antar Agama, (Jogjakarta: Yayasan Nida, 1970), hlm. 33-34
} 
lain bahwa seseorang harus mengikuti ajaran Islam, tetapi bagi yang meyakini Islam sebagai agamanya maka prinsip dalam menjalankan ajarannya harus kaffah ${ }^{12}$.

Islam sangat menghormati dan menghargai perbedaan, terlebih dalam urusan keyakinan terhadap agama. Setiap Muslim diberikan tugas untuk memberikan pemahaman terhadap nilai-nilai yang terkadung dalam ajaran Islam tanpa harus memaksakan kehendaknya dengan jalan kekerasan. Islam harus diterima dengan keinginan sendiri bukan dengan paksaan, keputusan tersebut harus dihormati dan selalu dijaga oleh setiap Muslim. Selain itu juga Islam sangat melindungi jaminan kebebasan setiap individu baik dalam mengeluarkan pendapat, kebebasan berserikat, kebebasan mengeluarkan ucapan hati nurani dan keyakinan ${ }^{13}$. Piagam Madinah sudah mengatur akan kebebasan dalam memeluk dan menjalankan suatu agama, kebebasan beragama bukan dimaksudkan untuk merusak agama, tetapi menjaga dan melindunginya agar hak-hak tersebut tidak disalahgunakan terutama pada kelompok minoritas ${ }^{\mathbf{1 4}}$.

Di Indonesia sendiri, kemajemukan mengenai agama merupakan suatu fakta sosiologis yang secara otomatis dikukuhkan dengan wacana politik sebagai hasil reformasi terhadap sikap keberagamaan. Dalam praktiknya mengakibatkan terjadinya transformasi kehidupan sosial keagamaan di Indonesia yang semakin terbuka lebar untuk berekspresi secara bebas. ${ }^{15}$

Intinya, Islam berpandangan bahwa setiap manusia mempunyai persamaan hak saat menentukan agama yang diyakininya. Hal tersebut telah dicontohkan Rasulullah SAW, beliau mampu memimpin dengan bijak dan mampu mewujudkan masyarakat madani meskipun berbeda kepercayaan satu sama lain.

Tujuan disyariatkannya Hukum Islam adalah terciptanya suatu

\footnotetext{
12 Muhammad Alim, Demokrasi dan Hak Asasi Manusia Dalam Konstitusi Madinah dan UUD 1945. Cet.1., (Yogyakarta: UII Press, 2001), hlm. 95-96

13 Maulana Abul A'la Maududi, Hak-Hak Asasi Manusia Dalam Islam, Diterjemahkan oleh Djajaatmadja dan Bambang Iriana, Cet. 2., (Jakarta: Bumi Aksara, 2000), hlm. 22

14 Sarah Larasati Mantovani, “Tinjauan Yuridis Undang-Undang No. 1 PNPS Tahun 1965 Tentang Pencegahan Penyalahgunaan Penodaan Agama Terhadap Kebebasan Beragama di Indonesia (Analisis Putusan Mahkamah Konstitusi No. 140/PUU-VII/2009)". Skripsi tidak diterbitkan. Tangerang Selatan: Fakultas Hukum Universitas Pamulang, 2011, hlm. 13

15 Dadang Kahmad, hlm. 22.
} 
kemaslahatan umat manusia, khususnya hifdz dien dalam rumusan maqashid al-Syari'ah. ${ }^{16}$ Oleh karena itu, dalam Islam perlindungan atas hak beragama menjadi sangat penting. Hak asasi berarti menggambarkan bentuk kekuasaan dasar yang bersifar imperatif. Ini mempunyai relevansi dengan konsep dalam Islam lebih spesifiknya tauhid. Tauhid merupakan ajaran untuk memurnikan keesaan Allah dan menjadikan Allah sebagai zat yang melekat dihati sehingga melahirkan keteguhan iman. Tauhid sendiri memberikan dampak terhadap pembebasan diri sekaligus pembebasan sosial yang merupakan implikasi dari paham egalitarianisme yakni paham yang menganggap jika seluruh umat manusia memiliki posisi yang sama dan yang membedakannya hanyalah derajat takwa.

\section{Dasar Kebebasan Beragama Al-Quran}

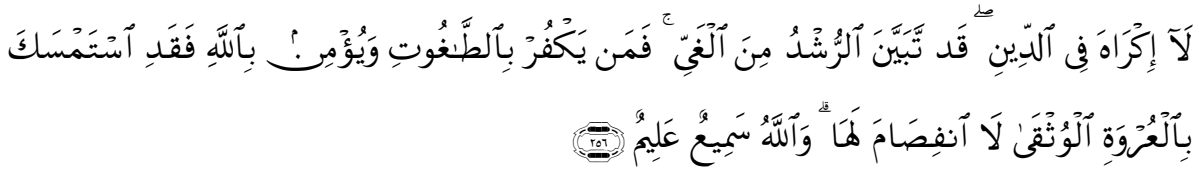

"tidak ada paksaan untuk (memasuki) agama (Islam); Sesungguhnya telah jelas jalan yang benar daripada jalan yang sesat. karena itu Barangsiapa yang ingkar kepada Thaghut dan beriman kepada Allah, Maka Sesungguhnya ia telah berpegang kepada buhul tali yang Amat kuat yang tidak akan putus. Dan Allah Maha mendengar lagi Maha mengetahui". (Q.S. Al-Baqarah Ayat 256)

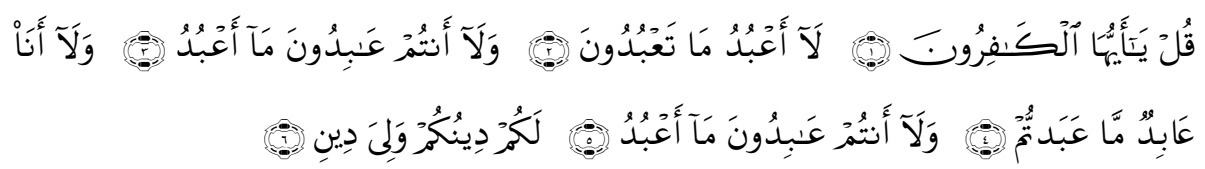

"Katakanlah (Muhammad), "Wahai orang-orang kafir! Aku tidak akan menyembah apa yang kamu sembah, dan kamu bukan penyembah apa yang aku sembah, dan aku tidak pernah menjadi penyembah apa yang kamu sembah, dan kamu tidak pernah (pula) menjadi penyembah apa yang aku sembah. Untukmu agamamu dan untukku agamaku" (Q.S. Al Kafirun Ayat 1-6).

16 Burhanuddin, Pemenuhan Hak-Hak Dasar Anak dalam Perspektif Islam, dalam Jurnal Adliya Volume 8 Nomor Edisi 1 Januari-Juni 2014, 289. 


\section{Piagam Madinah}

Perwujudan jaminan akan kebebasan beragama dan beribadah (freedom of religion) diatur dalam Piagam Madinah Pasal 25 dan ditegaskan kembali dalam pasal 26 sampai dengan pasal 35, yang artinya: "Kaum Yahudi Bani'Auf bersama dengan warga yang beriman adalah satu umah. Kedua belah pihak yakni kaum Yahudi dan kaum Muslimin bebas memeluk agama masing-masing. Demikian pula halnya dengan sekutu dan diri mereka sendiri. Bila di antara mereka ada yang melakukan aniaya dan dosa dalam hal ini, maka akibatnya akan ditanggung oleh diri dan warganya."

\section{Deklarasi Cairo}

Organisasi Konferensi Islam (OKI) pada tahun 1990 merupakan tombak sejarah disahkannya Deklarasi Cairo dengan beberapa poin sebagai berikut ${ }^{17}$ :

“(1) Kebebasan manusia dalam masyarakat Islam konsisten dengan esensi kehidupannya, karena manusia dilahirkan dalam keadaan bebas dan bebas dari tekanan dan perbudakan; (2) Persamaan adalah basis untuk memperoleh hak dan kewajiban asasi manusia; (3) Islam mengakui persamaan antara penguasa dan rakyat yang harus tunduk kepada hukum Allah untuk menuntut siapapun yang menggangu ketentraman masyarakat; (4) Islam mengakui persamaan semua manusia tanpa membedakan asal-usul, ras, jenis kelamin, warna kulit, dan bahasa."

Deklarasi Cairo terdiri dari 25 pasal. Dengan penjabaran dari keseluruhan pasal-pasal tersebut, yakni18:

"HAM dalam Islam bersifat komprehensif (sosial, politik, budaya, dan ekonomi); HAM dalam Islam adalah karunia Allah (fitrah) dan bukan dari pemberian sesama manusia; HAM dalam Islam tidak terpisahkan dari syariah; HAM dalam Islam diderivasi dari ajaran Islam, yakni pernyataan dalam surat al-Israa ayat 70 yang menerangkan bahwa manusia merupakan makhluk yang mulia; HAM dalam Islam tidak absolute, karena dibatasi oleh obyek-obyek syariah dan bertujuan untuk menjaga hak serta kepentingan tiap individu yang ada dalam masyarakat".

17 Hamid Fahmy Zarkasyi, Islam HAM Dan Kebebasan Beragama, (Jakarta: INSISTS, 2011), hlm. 4

18 Ibid., hlm. 5 


\section{Batasan Kebebasan Beragama}

Kebebasan beragama yang diberikan Islam mengandung sekurangnya tiga arti: “(1) Islam memberikan kebebasan kepada tiap individu untuk memeluk agama sesuai dengan kepercayaannya dan tidak ada paksaan bagi setiap individu untuk memeluk agama Islam; (2) Setiap Muslim tidak diperkenankan mengganti agama dan keyakinannya tanpa ada alasan yang dapat diterima oleh Islam; (3) Pemeluk agama Islam secara otomatis terikat oleh hukum-hukum yang ada di dalamnya, sehingga tidak diperkenankan membuat ajaran maupun tafsiran-tafsiran baru yang bertentangan dengan dasar-dasar teologis (syariah dan aqidah)".

Tidak dibenarkan seorang yang mengaku beragama melakukan sebuah tindakan penghinaan, melecehkan keyakinan agama lain, dan melakukan provokasi dalam permusuhan sesama umat. Sejatinya penyebaran informasi diperbolehkan selama tetap mengikuti pedoman-pedoman yang berlaku dan dilakukan dengan baik dalam koridor hukum yang jelas serta tidak menimbulkan bahaya bagi masyarakat dan negara ${ }^{19}$.

\section{Tujuan Kebebasan Beragama}

Kerukunan antar umat beragama merupakan perwujudan dari tercapainya kebebasan beragama. Kerukunan ini dapat terpelihara dengan baik apabila setiap individu dan/atau golongan agama dapat selalu memelihara identitas masing-masing tanpa harus ikut mencampuri keyakinan agama lainnya, tetap menghargai dan menghormati merupakan sebuah keharusan yang dijaga dengan sebaik mungkin. Sebagaimana Firman Allah SWT dalam Al-Quran:

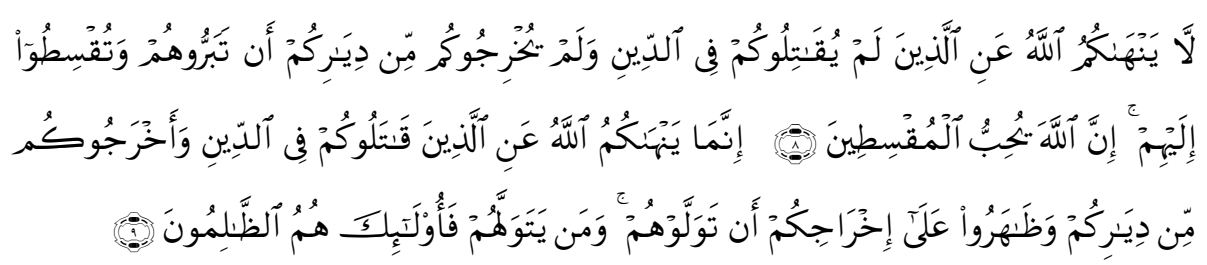

"Allah tidak melarang kamu berbuat baik dan berlaku adil terhadap orang-orang yang tidak memerangimu dalam urusan agama dan tidak mengusir kamu dari kampung halaman mu. Sesungguhnya Allah mencintai orang-orang yang berlaku adil. Sesungguhnya Allah hanya melarang kamu menjadikan mereka sebagai kawanmu orang-orang yang memerangi kamu dalam 
urusan agama dan mengusir kamu dari kampung halaman mu dan membantu (orang lain) untuk mengusirmu. Barangsiapa menjadikan mereka sebagai kawan, mereka itulah orang yang zalim" (Q.S. Al-Mumtahanah Ayat 8-9).

Harmonisasi keberagaman dalam bingkai kerukunan umat beragama dapat dicapai dengan saling menjaga toleransi, menghargai, menghormati dan saling pengertian serta senantiasa bekerjasama dalam hidup bermasyarakat berdasarkan nilai-nilai luhur Pancasila ${ }^{20}$.

\section{Prinsip Islam dalam Melindungi Hak Minoritas}

Saat ini umat Islam tengah menghadapi situasi yang dilematis. Di mana ada beberapa kegiatan yang dilakukan oleh oknum yang mengatasnamakan Islam sehingga menyudutkan Islam sebagai agama yang mengajarkan kekerasan dan intoleran. Anggapan tersebut tidaklah benar, pasalnya ketika Islam menjadi agama mayoritas, maka keberadaan agama minoritas dapat leluasa melakukan aktivitas beribadah. Akan tetapi berbanding terbalik ketika Islam yang menjadi minoritas, maka kebebasan dalam menjalankan ibadah cenderung dibatasi. Penganiayaan dan penindasan selalu menjadi potret buram yang seolah-olah dipandang sebelah mata oleh masyarakat internasional.

Sejarah mencatat, bahwa Islam dapat hidup berdampingan dengan komunitas minoritas dalam kondisi yang aman. Bahkan Nabi Muhammad SAW telah menyusun sebuah aturan yang menjamin terpeliharanya sebuah toleransi antara Islam dan agama lainnya dengan damai di Madinah yang dikenal dengan "Mitsaq al-Madinah"21. Di antara butir perjanjian itu berbunyi, "Orang-orang Yahudi Bani Auf adalah satu umat dengan orang-orang mukmin. Bagi orang-orang Yahudi adalah agama mereka dan bagi orang-orang Mukmin agama mereka, termasuk pengikut mereka dan diri mereka sendiri. Hal ini berlaku bagi orang-orang Yahudi selain Bani Auf"22.

${ }^{20}$ Ali Ahmad, Haidlor, Dinamika Kehidupan Keagamaan di Era Reformasi. Cet. 1. Jakarta: Kementerian Agama RI Badan Litbang dan Diklat Puslitbang Kehidupan Keagamaan, 2010, hlm. 14.

${ }^{21}$ Abdul Aziz Dahlan (et.al), Ensiklopedi Hukum Islam, Jilid 3, (Jakarta: PT Ichtiar Baru Van Hoeve, 1996), hlm. 1028-1032

22 Teks "Piagam Madinah" ini selengkapnya dapat dilihat dalam: Ibn Hisyam, AlSirah al-Nabawiyyah, hlm. 501. Lihat juga dalam: Saifurrah\}man al-Mubarakfury, Sirah Nabawiyyah, (Jakarta: Pustaka al-Kausar, Cet. 19, 2005), hlm. 255. 
Pengakuan akan prinsip pluralisme dan kemajemukan dalam kontek agama, ras, suku, dan budaya merupakan kehendak Allah SWT. Tetapi Islam tidak membenarkan bahwa semua agama sama, karena pandangan Islam bahwa perbedaan seorang muslim dengan non-muslim tercermin pada Akidahnya dalam memeluk agama Islam. Sehingga ini menjadi perbedaan yang fundamental dan tidak membenarkan agamaagama lain sama derajatnya dengan Islam ${ }^{23}$.

Kebebasan beragama sepenuhnya dijamin oleh Islam tanpa ada unsur paksaan bahkan ancaman. Pandangan Islam, bahwa setiap orang berhak memeluk agama berdasarkan keyakinannya. Tidak dibenarkan ada pemaksaan terhadap seseorang untuk meninggalkan agamanya dan memeluk agama lain, terlebih lagi memeluk agama Islam. Prinsip Islam dalam melindungi hak minoritas sangat dijaga dan dihormati sebagaimana terkandung dalam Al-Quran, diantaranya: Q.S. Yunus Ayat 99, Q.S. Al-Kahfi Ayat 29, dan Q.S. Al-Kafirun. Keseluruhan ayat-ayat tersebut tidak membenarkan adanya paksaan dalam memeluk agama Islam. Islam juga mengajarkan kepada umatnya tentang tuntunan dan etika dalam berdakwah dan berdialog dengan orang-orang non-Muslim. Islam dengan sangat tegas melarang umatnya untuk mencela sembahan-sembahan orang non-Muslim, hal ini sebagaimana yang difirmankan Allah dalam QS: al-An'am: 108.

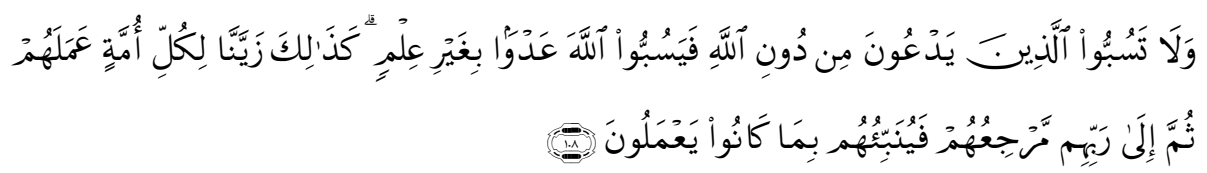

"dan janganlah kamu memaki sembahan-sembahan yang mereka sembah selain Allah, karena mereka nanti akan memaki Allah dengan melampaui batas tanpa pengetahuan. Demikianlah Kami jadikan Setiap umat menganggap baik pekerjaan mereka. Kemudian kepada Tuhan merekalah kembali mereka, lalu Dia memberitakan kepada mereka apa yang dahulu mereka kerjakan."

Perlindungan atas hak minoritas merupakan suatu bentuk perhatian utama dalam Islam bahkan setiap negara. Bukan semata-mata penegakan HAM, tetapi juga perwujudan stabilitas kawasan yang akan mendorong terciptanya keamanan dan perdamaian dunia. Di samping itu, langkah pertama perlindungan hak minoritas adalah pencegahan diskri-

${ }^{23}$ Ja'far Abd al-Salam, Al-Tasamuh fial-Fikri al-Islami, (Kairo: Rabit\}ah al-Jami'ah al-Islamiyyah, 1425/2005), hlm. 167. 
minasi secara politik, sosial ekonomi serta budaya dengan tujuan menyamakan kedudukan tanpa memberikan batasan berdarkan perbedaan satu sama lain. Islam sangat menghormati bahkan menghargai akan adanya perbedaan diantara sesama manusia. Bahkan dalam ajaran Islam, hubungan manusia sudah seharusnya meletakan perbedaan untuk saling melengkapi dan menjadi rahmat satu sama lain, bersifat mendamaikan dan bukan memicu konflik. Lebih dari demikian, Allah juga mengisyaratkan manusia dalam Al-Quran Surah Al-Rum ayat 22:

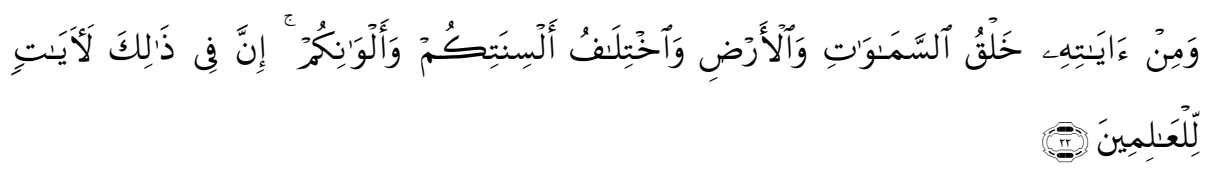

"dan di antara tanda-tanda kekuasaan-Nya ialah menciptakan langit dan bumi dan berlain-lainan bahasamu dan warna kulitmu. Sesungguhnya pada yang demikan itu benar-benar terdapat tandatanda bagi orang-orang yang mengetahui."

Intinya perbedaan diantara manusia yang meliputi bahasa, warna kulit, dan lain sebagainya merupakan sebuah isyarat untuk manusia yang senantiasa bertafakur. Melalui ayat di atas, Allah SWT sejatinya telah menggambarkan kekuasaannya, bahkan Allah SWT bisa saja membuat manusia menjadi satu umat yang sama rata dalam segi kondisi, agama, ras, etnis, warna kulit dan budaya. Tetapi dalam redaksi terakhir, isyarat Allah SWT lebih dominan dan menyatakan jika manusia yang mengakui akan adanya perbedaan adalah manusia yang cenderung inklusif dalam berfikir sehingga mampu mengetahui jika itu merupakan bagian dari kekuasaan Allah SWT.

Al-Quran secara tekstual tidak membicarakan secara jelas dan spesifik mengenai Hak Asasi Manusia. Hal itu dikarenakan Al-Quran merupakan sebuah kitab yang berisi pedoman dan bukan buku ilmiah yang secara tekstual menjabarkan akan sesuatu. Namun hebatnya AlQuran, di dalamnya memuat sejumlah tataran prinsip seperti mengajarkan nilai musyawarah, keadilan, kepedulian terhadap sesama, persamaan derajat atau menolak diskriminasi, perangai akhlak dan lain sebagainya. Konsep-konsep tersebut tidak lain merupakan penjabaran terhadap intisari nilai-nilai yang ada dalam Hak Asasi Manusia dan secara prinsipal saling terkait satu sama lain yang jika dipadukan akan memperoleh titik temu lebih rinci. 
Pada hakikatnya, Islam memang mengajarkan manusia menjadi muslim yang humanis, yakni muslim yang mampu berdamai dengan manusia lainnya, mereka yang menghindari sikap ekslusif, mereka yang mampu menghargai hingga bertoleransi dalam suatu ruang lingkup tertentu, serta mereka yang mampu menjadi penyangga bagi siapa saja yang berusaha untuk berdialektika dengan tujuan menjadi manusia idealis yang mampu ditempa dan dicetak. ${ }^{24}$

Pengakuan serta rasa aman akan ekistensi dapat menjadi suatu modal sosial bagi kelompok-kelompok etnik sebagai salah satu unsur kesukuan yang menyokong proses pembangunan. Dengan situasi kondusif perbedaan kelompok, etnis dan agama berpeluang besar, bersimbolis serta mampu hidup berdampingan secara harmonis tanpa harus kehilangan jati diri identitas primordialnya. ${ }^{25}$ Islam meninjau apapun yang menjadi legal, lurus dan sesuai dengan hukum Allah SWT yang adil. Hal demikian menjadi gambaran konsep religius, karena Islam mengatur mengenai norma-norma keseimbangan, yang apabila tercapai semua tingkah laku maka akan terciptanya keadilan yang diterima masyarakat. ${ }^{26}$

Lebih jauh dari hal itu, Islam memandang kerukunan tidak menisbikan berbagai perbedaan yang ada di lain pihak tidak mengabsolutkan perbedaan yang ada sehingga akan mengancam serta menutup gerbang hubungan. Sebab, hubungan yang kondusif keagamaannya dapat dirasakan membawa kebangkitan iman penganutnya bukan sekedar perhitungan untung rugi, bersifat sosiologis-pragmatis, namun tetap terlahir sebagai ekspresi iman serta ekspresi tindakan iman. Hal ini memiliki makna ganda yakni ketaatan iman kepada Tuhan yang harus dinyatakan melalui sikap tulus serta terbuka dalam menjalin hubungan dengan orang yang berlainan agama dan keyakinan. Kemudian hubungan dengan yang beriman lainnya hanya bisa dilakukan dengan ketaatan iman kepada Tuhan. Inilah yang diajarkan Islam, yakni memacu semangat kerukunan bergama yang lahir dari iman. Hal tersebut dikarenakan spirit kerukunan tidak sedikit mengurangi semangat missioner, seperti halnya kerukunan umat beragama tidak harus dipertentangkan dengan kebebasan serta amanat Allah swt. untuk saling mengasihidan menghormati. hlm. 56.

${ }^{24}$ Linda Novianti, Pesan Cinta Sufisme Untuk Milenial, (Bandung :FITRAH), 2019,

25 Dadang Kahmad, hlm. 196.

26 Mardani, Etika Profesi Hukum, (Depok : PT. Raja Garfindo Persada, Cetakan ke2, 2019), hlm. 48 . 
Nilai agama, sangatlah dibutuhkan pada masa sekarang sebab cukup relevan bagi bangsa Indonesia. Hal ini dikarenakan Pancasila yang pertama yakni Ketuhanan Yang Maha Esa selaras dengan prinsip tauhid yang sangat rasional serta tidak bersifat abstrak dalam persepsi ketuhanan. Sila pertama tersebut merupakan bentuk yang menyokong Pancasila sebagai asas negara yang juga diakui oleh agama-agama lain. Kemudian jika mengacu terhadap nilai solidaritas dalam Islam, terlihat jelas tidak membedakan asal usul, ras, agama maupun warna kulit.

Islam hadir untuk mendorong terciptanya rasa aman dan damai bagi agama minoritas dalam melaksanakan kewajibannya sebagai umat beragama. Islam sebagai agama yang mengajarkan kepada umatnya bahwa kemajemukan dan pluralitas merupakan sunatullah yang tidak perlu dipersoalkan selama hal tersebut tidak bertentangan dengan prinsip-prinsip keimanan dan Hak Asasi Manusia. Kemudian Islam meninjau bahwa perlindungan hak minoritas merupakan pencegahan diskriminasi secara ekonomi, sosial, budaya, politik dan hukum dengan tujuan menyamakan kedudukan tanpa memberikan batasan berdasarkan perbedaan satu sama lain.

\section{Penutup}

Hakikatnya manusia terlahir dalam keadaan merdeka (freedom) dan suci, maksudnya hak ini merupakan sesuatu yang mutlak dimiliki oleh setiap manusia dalam bingkai kehidupannya di dunia. Begitupun dengan kebebasan dalam menjalankan keyakinannya kepada Tuhan Yang Maha Esa tidak dapat diinterpensi oleh siapapun. Kebebasan tersebut menjadi sebuah keharusan bahwa hak-hak tersebut dilindungi baik oleh kelompok mayoritas maupun Hak Asasi Manusia dalam hal berkumpul, memberikan penerangan, menerima, dan mengajarkan agama.

Islam sangat menghormati dan menghargai perbedaan, terlebih dalam urusan keyakinan terhadap agama. Setiap Muslim diberikan tugas untuk memberikan pemahaman terhadap nilai-nilai yang terkadung dalam ajaran Islam tanpa harus memaksakan kehendaknya dengan jalan kekerasan. Islam harus diterima dengan keinginan sendiri bukan dengan paksaan, keputusan tersebut harus dihormati dan selalu dijaga oleh setiap Muslim.

Islam mengajarkan manusia menjadi muslim yang humanis, yakni muslim yang mampu berdamai dengan manusia lainnya, mereka yang 
menghindari sikap ekslusif, mereka yang mampu menghargai hingga bertoleransi dalam suatu ruang lingkup tertentu, serta mereka yang mampu menjadi penyangga bagi siapa saja yang berusaha untuk berdialektika dengan tujuan menjadi manusia idealis yang mampu ditempa dan dicetak.

Islam hadir untuk mendorong terciptanya rasa aman dan damai bagi agama minoritas dalam melaksanakan kewajibannya sebagai umat beragama. Islam sebagai agama yang mengajarkan kepada umatnya bahwa kemajemukan dan pluralitas merupakan sunatullah yang tidak perlu dipersoalkan selama hal tersebut tidak bertentangan dengan prinsip-prinsip keimanan dan Hak Asasi Manusia. Kemudian Islam meninjau bahwa perlindungan hak minoritas merupakan pencegahan diskriminasi secara ekonomi, sosial, budaya, politik dan hukum dengan tujuan menyamakan kedudukan tanpa memberikan batasan berdasarkan perbedaan satu sama lain.

\section{Daftar Pustaka}

Ali Ahmad, Haidlor, "Dinamika Kehidupan Keagamaan di Era Reformasi". Cet. 1. Jakarta: Kementerian Agama RI Badan Litbang dan Diklat Puslitbang Kehidupan Keagamaan, 2010.

Ali, Mukti, “Dialog Antar Agama”, Jogjakarta: Yayasan Nida, 1970.

Alim, Muhammad, "Demokrasi dan Hak Asasi Manusia Dalam Konstitusi Madinah dan UUD 1945”. Cet.1., Yogyakarta: UII Press, 2001.

al-Maududi, Abu A'la, Hak Asasi Manusia dalam Islam, Jakarta : YAPI, 1998.

"Hak-Hak Asasi Manusia Dalam Islam", Diterjemahkan oleh Djajaatmadja dan Bambang Iriana, Cet. 2., Jakarta: Bumi Aksara, 2000.

al-Mubarakfury, Saifurrahman, Sirah Nabawiyyah, Jakarta: Pustaka alKausar, Cet. 19, 2005.

al-Salam, Ja'far Abd, Al-Tasamuh fial-Fikri al-Islami, Kairo: Rabit\}ah alJami'ah al-Islamiyyah, 1425/2005.

Atqiya, Naimatul, "HAM dalam Perspektif Islam", dalam Jurnal Islamuna Nomor 1 Volume 2 (Desember 2014).

Burhanuddin, Pemenuhan Hak-Hak Dasar Anak dalam Perspektif Islam, 
dalam Jurnal Adliya Volume 8 Nomor Edisi 1 Januari-Juni 2014.

Dahlan, Abdul Aziz (et.al), Ensiklopedi Hukum Islam, Jilid 3, Jakarta: PT Ichtiar Baru Van Hoeve, 1996.

Fadhli, Yogi Zul, "Kedudukan Kelompok Minoritas dalam Perspektif HAM dan Perlindungan Hukumnya di Indonesia", dalam Jurnal Konstitusi, Volume 11, (Nomor 2, Juni 2014).

Hawa, Said, Al-Islam, Terj. Abdul Hayyi al-Kattani dkk, Jakarta: Gema Insani Press, 2004.

Ibn Taimiyah, Majmu' Fatawa, Juz: 18, Tahqiq: Anwar al-Baz dan 'Amir alJazar, Daar al-Wafa', Cet. 3, 1426 H.

Kahmad, Dadang, Multikulturalisme Islam dan Media, Bandung : Pustaka Djati, 2013.

Mantovani, Sarah Larasati, Tinjauan Yuridis Undang-Undang No. 1 PNPS Tahun 1965 Tentang Pencegahan Penyalahgunaan Penodaan Agama Terhadap Kebebasan Beragama di Indonesia (Analisis Putusan Mahkamah Konstitusi No. 140/PUU-VII/2009). Skripsi tidak diterbitkan. Tangerang Selatan: Fakultas Hukum Universitas Pamulang, 2011.

Mardani, Etika Profesi Hukum, Depok: PT. Raja Garfindo Persada, Cetakan ke-2, 2019.

Nazir, Moh., Metode Penelitian. Bandung: Ghalia Indonesia, 2003.

Novianti, Linda, Pesan Cinta Sufisme Untuk Milenial, Bandung: FITRAH, 2019.

Solikhin, Akhmad, "Islam, Negara, dan Perlindungan Hak-Hak Islam Minoritas", dalam Journal of Governance, Volume 1, Nomor 2, Desember 2016.

Sukanto, Suerjono dan Mamudji, Sri, Penelitian Hukum Normatif Suatu Tinjauan Singkat, Cet. 11 Jakarta: PT. Raja Grafindo Persada, 2009.

Wijaya, Endra, Problem Melindungi Hak Beragama dan Berkeyakinan Bagi Kelompok Minoritas, Jurnal Yudisial Vol. 10 No. 2 Agustus 2017.

Zarkasyi, Hamid Fahmy, Islam HAM dan Kebebasan Beragama, Jakarta: INSISTS, 2011. 
242 | Adliya: Jurnal Hukum dan Kemanusiaan, Vol. 14, No. 2, Desember 2020

[Halaman ini sengaja dikosongkan] 